\title{
The Power of Will to Survive: A Case Report
}

\author{
Gitumoni Konwar ${ }^{1}$, Urmijyoti Deori ${ }^{2}$, \\ ${ }^{1}$ Director Research and Outreach, Faculty of Nursing, Assam Down Town University, Assam. \\ ${ }^{2}$ Associate Professor, Rahman Institute of Nursing and Paramedical Sciences, Assam.
}

Corresponding Author: Urmijyoti Deori

\begin{abstract}
The will to survive is very essential for someone to keep himself struggle until he survives a dreadful situation. This perfectly matches with a case of a man surviving an accident. A 35 year old man met with an accident and fell into a ditch with his motorbike on top of him and the handle of the motorbike pressed his vocal cord. Nobody noticed him falling into the ditch nor could he shout for help. He was all alone by himself in an isolated area where no help will arrive unless somebody sees him. He fell on the ground where the area of the soil under his head was raised which made even harder for him to move his head and free his vocal cord. To save himself he dug out the soil under his head so that he could move his head by creating some space by reducing the bumpiness of the soil. After digging out the soil for several hours he finally could move his head and free his vocal cord too. He shouted for help and soon some people gathered there who took him to the hospital. The victim suffered cervical injury, bruises and cuts on his body along with psychological trauma.
\end{abstract}

Key words: will power, survival, struggle, accident, dreadful situation

\section{INTRODUCTION}

The will to survive is the basic instinct of human beings and animals which drive them to protect themselves from any potential life threatening situations. We all have developed the survival behavior from our childhood and we all are day-to-day survivors. Today we are alive because of this survival behavior which helps us to adapt ourselves to the external environment and circumstances ${ }^{1}$.
The will to survive is very much crucial to carry out all the activities which are essential to do in order to survive in the moments where life is endangered. This can be related to "do or die" situations where either one has to fight for survival or embrace the death. Studies say that people who have a strong desire to live and are laden with many responsibilities to be carried out in their lives often appear fare better than those who perceive no meaning in their lives in such dreadful situations. It is a well established statement that the strong will power can actually prolong ones' life span and increase the chances of survival. ${ }^{2}$

A study was done on the relationship between will to live and death-related decline in life satisfaction. The result revealed that if there is any life threatening situation, the death is more predictive in those whose life satisfaction is declined than those with a strong will power to live. ${ }^{3}$ There are many survival tales like plan crash, accidents, prisoner-of-war, concentration camps etc, where human beings endured the entire ordeal and survived. Survivors must have the never giving up and losing the hope attitude. ${ }^{4}$

\section{CASE REPORT}

A 35 year old man was travelling on his motor bike on a highway when he met with an accident and fell into a ditch which was quite deep and isolated. He fell on his back with the motor bike on top of him and the handle of the motor bike above his neck. He could not remove the bike from top of him as it was heavily pressing his body 
including right hand. He decided to seek for help. He tried to shout but, no sound was coming out as the handle of the motorbike was pressing it. Many people were passing by the road without any clue that someone is in great need of help down the road. He put all his effort to remove the bike from his body but was unable to do that. His head fell on a bumpy (raised) area of the ground which made more difficult for him to move his head. After doing many unsuccessful attempts to remove the bike above him, he decided to dig out the bumpy soil under his head by his only free left hand. He started digging out the soil under his head so that he can create some space by reducing the bumpiness and enable him to pull up his body through his head.

He was very much exhausted by digging out the soil for many hours but still could not succeed to move himself. He gave up at one point and accepted that this is going to be his last day of life. After staying still for some time he summoned up his energy and started digging again which finally made him pull up his body by his head supported by his right hand. As soon as he could free his vocal cord, he sought for help. People gathered after few minutes and he was transferred to the nearby hospital.

\subsection{Investigations}

The victim was advised to do X-ray of Cervical spine AP and Lateral view, flexion and extension view. He was also advised to do MRI of Cervical spine.

\subsection{Injuries sustained}

The victim suffered $\mathrm{C}_{2}$ bilateral fractures of lamina and $\mathrm{C}_{7}$ spinous process fracture with severe neck pain. MRI study revealed mild grade-I anterolisthesis of $\mathrm{C}_{2}$ over $\mathrm{C}_{3}$ vertebral bodies with defects in posterior arch of $\mathrm{C}_{2}$ vertebra. Spinal cord appeared normal. There was also damage to the cartilage due to which he had clicking sensation while moving neck. He also suffered injuries in his body, right hand fingers and nails. There were cuts and bruises on the fingers and palm, and the nails broke far down. He was hospitalized for five days.

\subsection{Treatment: The victim was treated with}

i. tablet Acemyoset 1 tablet daily for 2 weeks. Acemyoset is an NSAIDS which works by blocking the release of certain chemical messengers that cause pain and inflammation.

ii. Tab Depran 10mg $1 \mathrm{tab}$ at bed time for 1 month.

Depran is used to treat anxiety disorder. It helps to calm the brain by decreasing the excessive activity of the nerve cells. It also increases the level of chemical messenger which improves mood.

iii. Pantodac $40 \mathrm{mg} 1$ tab before breakfast for two weeks.

It is used to treat acid related diseases. It is also used to prevent acidity associated with the use of painkillers.

iv. Neck movement restriction with the help of cervical collar for one month and advised to follow up after one month.

\section{Psychological reactions to traumatic event}

At first the victim was bewildered by the horrific situation when he fell into the ditch and could not clearly think what to do. After sometime he managed to keep calm and think rationally to save himself. $\mathrm{He}$ decided to dig out the soil under his head to be able to pull up his body through his head to escape. He tried so hard to escape by digging soil for several hours but could not succeed. At one point he got totally exhausted and gave up all his hopes of surviving and got mental breakdown thinking that he is going to die soon. When some more time passed, he started accepting his death and closed his eyes. He had flashback of all the beautiful memories of his life. He imagined his brothers and sisters smiling, friends laughing and parents advising and caring him. His mind was consumed by all those imaginations and he thanked god for giving him a chance to live 
with his loved ones. He was also remembering the responsibilities that he has for being the eldest son. Then all of a sudden his mood was lifted and he thought of giving one more try. He gathered back all his energy and started digging out soil under his head again. He dug out the soil for several minutes more and finally all his hard work paid off. He managed to move himself by pulling up his body through his head and make free the vocal cord.

After that he sought for help and took deep breaths of respite. His whole body was shaking and he could not believe that he has actually cheated his death right now.

\section{CONCLUSION}

There is a great power in the will to survive. People with strong will to live will survive more often in a dreadful event. Their dreams, aspirations, responsibilities, expectations etc keep them fight for their survival. In such conditions at the beginning, most of the people will get panicked and mentally paralyzed where they cannot think rationally. Then slowly they regain their senses and start to plot and execute accordingly to survive. Many studies say that people who have a purpose to live will not give up easily in such extreme situations.

\section{Acknowledgement: None}

Conflict of Interest: None

\section{Source of Funding: None}

\section{REFERENCES}

1. Chochinov Harvey Max, Hack Thomas, Hassard Thomas et.al. Understanding the will to live in patients nearing death. The Academy of Psychosomatic medicine. JanFeb 2005; 46(1):7-10.

2. Bomet Marc- Antoine, Bernard Mathieu, Jaques Cecile et.al. Assessing the will to live: A scoping review. Journal of pain and symptom management. 2020 Sep 12; S0885-3924(20) 30740-5.

3. Carmel S, Shrira A, Shmolkin D. The will to live and death- related decline in life satisfaction. Psychology and ageing. 2013; 28(4):1115-1123

4. Leach John. Survival Psychology: the won't to live. The British psychological society. [Internet]. 2011. [updated 2011 Jan; cited 2021 Mar. 23].

How to cite this article: Konwar G, Deori U. The power of will to survive: a case report. International Journal of Science \& Healthcare Research. 2021; 6(2): 123-125. DOI: https://doi.org/10.52403/ijshr.20210422 